\title{
Chylous ascites in cirrhosis-A case report
}

\author{
S. Laudari ${ }^{1}$, K Subedi $^{2}$, R.Toyena ${ }^{3}$, J.Vamja ${ }^{4}$, S.Nanda Kumar ${ }^{5}$, S.Subedi ${ }^{6}$ \\ ${ }^{1}$ Lecturer, ${ }^{2}$ Medical Officer, ${ }^{3}$ Junior Resident, ${ }^{4}$ Intern, ${ }^{5}$ Associate professor, ${ }^{6}$ Junior resident, Department \\ of Medicine, College of Medical Sciences, Bharatpur, Chitwan, Nepal
}

\begin{abstract}
Chylous ascites is a rare presentation in cirrhotic liver disease but its incidence has increased because of aggressive cardiothoracic/abdominal surgeries and increasing survival of patients with chronic liver disease and cancer. We report here a case presenting with spontaneous chylous ascites in cirrhosis of liver. It has been associated with poor prognosis.
\end{abstract}

Keywords: chylous ascites, cirrhosis, poor prognosis.

\section{Introduction}

Chylous ascites is the accumulation of a milk-like peritoneal fluid rich in triglycerides due to the presence of thoracic or intestinal lymph in the abdominal cavity. ${ }^{1}$ It is an uncommon finding with reported incidence of only one in 20,000 admissions at a large universitybased hospital over a 20 -years period. ${ }^{2}$ In western countries, abdominal malignancy and cirrhosis account for over two third of all cases of chylous ascites. In contrast, infectious etiologies eg.tuberculosis are responsible for majority of cases in developing countries. Other causes of chylous ascites include congenital, inflammatory, postoperative and traumatic. Diagnosis is readily made by the presence of milky and creamy ascitic fluid with a triglyceride content above $200 \mathrm{mg} / \mathrm{dl} .^{1,3}$ Spontaneous development of chylous ascites in patients with cirrhosis has a documented incidence of only $0.5 \% .{ }^{4}$ Unnecessary,

Correspondence: S. Laudari

E-mail: 1shankar2@hotmail.com expensive and invasive diagnostic modalities should be avoided in cirrhotic patients unless there is strong suspicion of malignancy.

\section{Case report}

32 years male from Hetauda, Makwanpur, Nepal (IP No:4336) was admitted at CMS-Teaching Hospital, Bharatpur for evaluation, diagnosis and management of progressive abdominal swelling for 6 months. His primary complaints also included anorexia and weight loss. Bowel and bladder functions were normal. There was no history of fever, altered sensorium, melena or hematemesis. He was a diagnosed case of Type 1 Diabetes Mellitus on regular insulin therapy for the past few months. He was an ex-smoker with index of 150 and regular alcoholic with consumption of locally made alcohol 4units/day for 18years which he left about 6 months back.Clinical examination revealed lean and thin male with BMI of $17.5 \mathrm{~kg} / \mathrm{m}^{2}$.Vitals at the time of presentation were: BPof 100/60mmHg,Pulse=88/ 
min,regular,good volume, temperature $=$ normal, respiration rate $=20 / \mathrm{min}$, regular. Jugular venous pressure was normal. Icterus was absent.Other positive clinical findings were mild pedal edema, ascites, prominent superficial abdominal veins(direction of blood flow-away from umbilicus), mild hepatomegaly with irregular border and splenomegaly.Cardiovascular system, central nervous system and chest examination were normal.Patient had stigmata of chronic liver disease with loss of secondary sexual characteristics.Routine and diagnostic tests were as shown in Table 1.
Surprisingly, peritoneal fluid tapping revealed gross milky fluid (Fig.1)which was further investigated for triglyceride $>200 \mathrm{mg} / \mathrm{dl}(430.8 \mathrm{mg} / \mathrm{dl})$ and no evidence of infection or trauma thus confirming chylous ascites in a patient with chronic liver disease with cirrhosis of liver with portal hypertension who is also known diabetic for few months. The patient was managed with therapeutic paracentesis, diuretics, propranolol (a beta blocker), antibiotics, insulin therapy and dietary control. He was discharged after he improved with the therapeutic measures.

\begin{tabular}{|c|c|c|c|c|}
\hline $\begin{array}{l}\text { Complete } \\
\text { hemogram }\end{array}$ & $\begin{array}{c}\text { Liver function } \\
\text { tests }\end{array}$ & $\begin{array}{l}\text { Radiological } \\
\text { investigations }\end{array}$ & $\begin{array}{l}\text { Peritoneal fluid } \\
\text { tapping }\end{array}$ & Others \\
\hline $\begin{array}{l}\text { Hb-14.4, } \\
\text { Hct-0.44, } \\
\text { WBC-7.7 } \\
\text { RBC-4.8, } \\
\text { Platelet-22 } \\
\text { 5DLC: N-80, } \\
\text { L-15, } \\
\text { E-02, } \\
\text { M-03 } \\
\text { ESR- 10mm in } 1^{\text {st }} \mathrm{hr} \\
\text { MCV-93.3 } \\
\text { FLMCH- } 29.9 \mathrm{pg} \\
\text { MCHC-32.0g/dl }\end{array}$ & $\begin{array}{l}\text { Total bilirubin:1.5mg/dl } \\
\text { Direct:0.6mg/dl } \\
\text { Indirect:0.9mg/dl } \\
\text { ALT:90IU/L } \\
\text { AST:110IU/L } \\
\text { Alkaline } \\
\text { phosphatase:122IU/L } \\
\text { Gamma-GT:200IU/L } \\
\text { Protein:5.8mg/dl } \\
\text { Albumin: } 2.6 \mathrm{~g} / \mathrm{dl} \\
\text { PT:16seconds } \\
\text { INR:1.4 }\end{array}$ & $\begin{array}{l}\text { USG abdomen:Liver } \\
\text { enlarged in size } \\
\text { measuring 144mm } \\
\text { with irregular outline } \\
\qquad \& \text { coarse } \\
\text { echotextureUrinary } \\
\text { bladder(UB): } \\
\text { Echogenic debri in } \\
\text { UBGross free fluid is } \\
\text { seen in abdomen and } \\
\text { pelvisCXR(PA view): } \\
\text { Rt. sided mild pleural } \\
\text { effusion }\end{array}$ & $\begin{array}{l}\text { Colour:milky fluid } \\
\text { Albumin:0.4 gm/dl } \\
\text { Protein: } 1.1 \mathrm{gm} / \mathrm{dl} \\
\text { SAAG:2.2(>1.1) } \\
\text { Sugar: } 330.4 \mathrm{mg} / \mathrm{dl} \\
\text { Triglyceride: } \\
\text { 430.8mg/dl } \\
\text { Grams stain- no } \\
\text { inflammatory cells, no } \\
\text { organism seen. } \\
\text { Z.N. stain- no } \\
\text { AFB seen. }\end{array}$ & $\begin{array}{c}\text { Upper } \\
\text { gasterointestinal } \\
\text { endoscopy: Grade I } \\
\text { esophageal } \\
\text { varicesFBS: } 252 \mathrm{mg} / \mathrm{dl} \\
\text { PPBS(2hrs):386mg/dl } \\
\text { Urine R/E and } \\
\text { microscopy:sugar(++) } \\
\text { Urine for ketone } \\
\text { bodies:-ve } \\
\text { Blood urea: } 47 \mathrm{mg} / \mathrm{dl} \\
\text { Serum Cr: } 1.2 \mathrm{mg} / \mathrm{dl} \\
\text { SerumNa:136meq/L } \\
\text { Serum K:3.5meq/L } \\
\text { Lipid profile: Total } \\
\text { cholesterol:165mg/dl } \\
\text { Triglyceride: } 88.4 \mathrm{mg} / \mathrm{dl} \\
\text { HDL: } 24 \mathrm{mg} / \mathrm{dl} \\
\text { LDL: } 123.4 \mathrm{mg} / \mathrm{dl} \\
\text { VLDL: } 17.6 \mathrm{mg} / \mathrm{dl}\end{array}$ \\
\hline
\end{tabular}


Fig 1:Picture showing chylous fluid on paracentesis abdominis

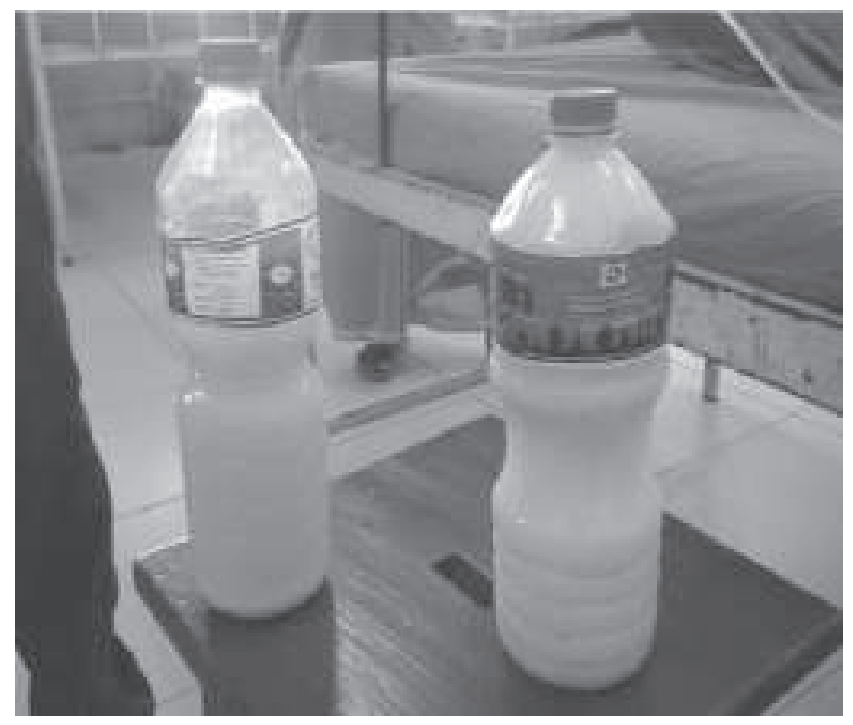

Fig 2: USG showing liver cirrhosis

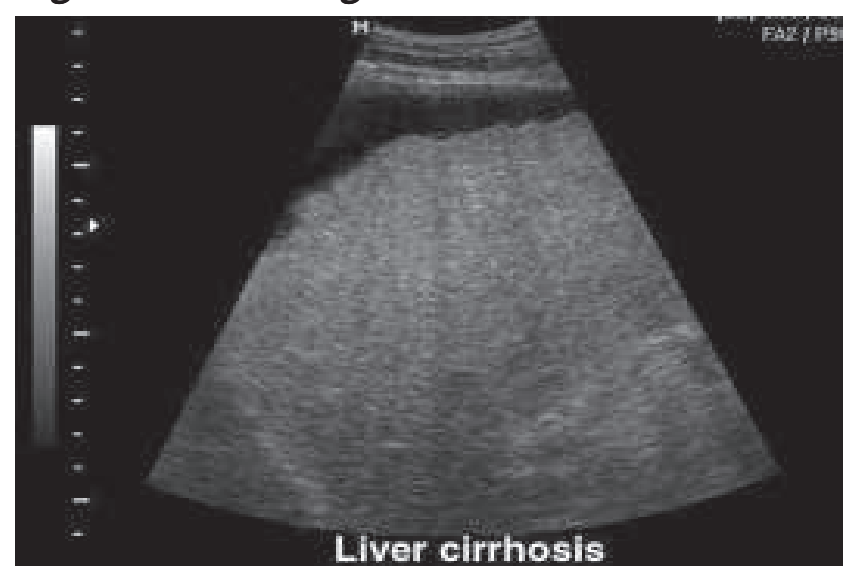

Discussion

The underlying pathophysiology of chylous ascites in cirrhosis of liver is due to rupture of serosal lymphatic channels which are dilated because of excessive lymph flow ${ }^{1}$. They present as progressive and painless abdominal distension which occurs over the course of weeks to months. Stigmata of chronic liver disease eg.jaundice, palmar erythema, spider angioma and encephalopathy may be present.

Abdominal paracentesis is the most important diagnostic tool in evaluating and managing patients with ascites.
Typically, chyle has a cloudy and turbid appearance with triglyceride values above $200 \mathrm{mg} / \mathrm{dl}^{3}$ although some authors use a cutoff value of $110 \mathrm{mg} / \mathrm{dl}^{2}$.

CT abdomen is useful in identifying pathological intraabdominal lymph nodes and masses. Lymphangiography and lymphoscintigraphy help in detecting abnormal retroperitoneal nodes, leakage from dilated lymphatics, fistulisation and patency of the thoracic duct. ${ }^{5}$

There are limited studies addressing the best treatment regimens. Most chylous effusions respond to an initial approach with high protein and low fat diet with medium chain triglycerides by reducing the production and flow of chyle. ${ }^{6}$ Patients with cirrhotic chylous ascites should be managed with low sodium diet and diuretics such as spironolactone. ${ }^{7}$ Patients who do not respond to the above measures should be fasted to reduce lymph flow and started on total parenteral nutrition(TPN). ${ }^{1}$ Somatostatin and octreotide have been successfully used to treat chylous effusions due to lymphatic leakage. It has been speculated that somatostatin improves chylous ascites by inhibition of lymph fluid excretion through specific receptors found in the normal intestinal wall of lymphatic vessels. ${ }^{8}$ Treatment of underlying cause is of pivotal significance. Repeated large volume paracentesis is a reasonable option for patients with end stage disease not amenable to medical or surgical treatment.

In patients who are poor surgical candidates and refractory to non-operative treatment, peritoneovenous shunting may be an option. High viscosity of the chyle results in shunt occlusion in the majority. ${ }^{9}$ Other complications include sepsis, disseminated intravascular 
S. Laudari et al. Chylous ascites in cirrhosis-A case report coagulopathy, electrolyte imbalance, small bowel obstruction and increased risk for air embolism.

\section{Conclusion}

Chylous ascites is a relatively uncommon disorder. Diagnosis of chylous ascites can be readily made with simple tests. In patients with cirrhosis, unless there is strong suspicion of malignancy, unnecessary, expensive and invasive diagnostic modalities to rule out a malignant process should be avoided. Treating the underlying disorder is of paramount importance in the management.

\section{References}

1. A. Cardenas, S. Chopra. Chylous Ascites. The American Journal of Gastroenterology 2002;97:8.

2. O.W. Press, N.O. Press, S.D. kaufman. Evaluation and management of chylous ascites. Ann Intern Med 1982;96:358-64.

3. Bruce A Runyon. Ascites and Spontaneous Bacterial Peritionitis. In:Feldman:Sleisenger and Fordtran's
Gastrointestinal and Liver Disease, $7^{\text {th }}$ ed. Elsevier 2002,78:1517-27.

4. W.G. Rector. Spontaneous chylous ascites of cirrhosis. J Clin Gastroenterol 1984;6:369-72.

5. M.H. Pui, T.C. Yueh. Lymphoscintigraphy in chyluria, chyloperitoneum and chylothorax. I Nucl Med 1998;39:1292-6.

6. S.K. Ohri, T. Patel, L.A. Desa. The management of postoperative chylous ascites. A case report and literature review. J Clin Gastroenterol 1990;12:693-7.

7. J. Uriz, A. Cardenas, V. Arroyo. Pathogenesis, diagnosis and treatment of ascites in cirrhosis. Baillieres Best Pract Res Clin Gastroenterol 2000;14:927-43.

8. A.M. Shapiro, V.G. Bain, D.L. Siagalet et al. Rapid resolution of chylous ascites after liver transplantation using somatostatin analog and total parenteral nutrition. Transplantation 1996;61:1410-1.

9. D. Voros, S. Hadziyannis. Successful management of postoperative chylous ascites with a peritoneo-jugular shunt. J Hepatol 1995;22:380. 